\title{
Quantification of chemical contaminants in the paper and board fractions of municipal solid waste
}

Pivnenko, Kostyantyn; Olsson, Mikael Emil; Götze, Ramona; Eriksson, Eva; Astrup, Thomas Fruergaard

Published in:

Waste Management

Link to article, DOI:

10.1016/j.wasman.2016.03.008

Publication date:

2016

Document Version

Peer reviewed version

Link back to DTU Orbit

Citation (APA):

Pivnenko, K., Olsson, M. E., Götze, R., Eriksson, E., \& Astrup, T. F. (2016). Quantification of chemical contaminants in the paper and board fractions of municipal solid waste. Waste Management, 51, 43-54. https://doi.org/10.1016/j.wasman.2016.03.008

\section{General rights}

Copyright and moral rights for the publications made accessible in the public portal are retained by the authors and/or other copyright owners and it is a condition of accessing publications that users recognise and abide by the legal requirements associated with these rights.

- Users may download and print one copy of any publication from the public portal for the purpose of private study or research.

- You may not further distribute the material or use it for any profit-making activity or commercial gain

- You may freely distribute the URL identifying the publication in the public portal 
Manuscript accepted for publication in Waste Management journal:

\title{
QUANTIFICATION OF CHEMICAL CONTAMINANTS IN THE PAPER AND BOARD FRACTIONS OF MUNICIPAL SOLID WASTE
}

\author{
K. PIVNENKO*, M. E. OLSSON, R. GÖTZE, E. ERIKSSON, T. F. ASTRUP \\ Department of Environmental Engineering, Technical University of Denmark, DK-2800 Kgs. \\ Lyngby, Denmark
}

*) Corresponding author: Kostyantyn Pivnenko

Department of Environmental Engineering, Technical University of Denmark, DK-2800 Kgs.

Lyngby, Denmark

pivnenko.k@gmail.com

Telephone: +45 4525 1602, fax: +45 45932850

"NOTE: this is the author's version of a work that was accepted for publication in Waste Management journal. Changes resulting from the publishing process, such as peer review, editing, corrections, structural formatting, and other quality control mechanisms may not be reflected in this document. Minor changes may have been made to this manuscript since it was accepted for publication. A definitive version is published in Waste Management, doi: 10.1016/j.wasman.2016.03.008” 


\begin{abstract}
Chemicals are used in materials as additives in order to improve the performance of the material or the production process itself. The presence of these chemicals in recyclable waste materials may potentially affect the recyclability of the materials. The addition of chemicals may vary depending on the production technology or the potential end-use of the material. Paper has been previously shown to potentially contain a large variety of chemicals. Quantitative data on the presence of chemicals in paper are necessary for appropriate waste paper management, including the recycling and re-processing of paper. However, a lack of quantitative data on the presence of chemicals in paper is evident in the literature. The aim of the present work is to quantify the presence of selected chemicals in waste paper derived from households. Samples of paper and board were collected from Danish households, including both residual and source-segregated materials, which were disposed of (e.g., through incineration) and recycled, respectively. The concentration of selected chemicals was quantified for all of the samples. The quantified chemicals included mineral oil hydrocarbons, phthalates, phenols, polychlorinated biphenyls, and selected toxic metals $(\mathrm{Cd}, \mathrm{Co}, \mathrm{Cr}, \mathrm{Cu}, \mathrm{Ni}$, and $\mathrm{Pb}$ ). The results suggest large variations in the concentration of chemicals depending on the waste paper fraction analysed. Research on the fate of chemicals in waste recycling and potential problem mitigation measures should be focused on in further studies.
\end{abstract}

Keywords: additives, EDCs, MSW, organic pollutants, recycling, phthalates 


\section{Introduction}

Material recycling and the substitution of virgin natural resources is generally considered to be beneficial for society. Recycling contributes to increasing resource efficiency in society, diverting waste from landfills, and minimizing the environmental impacts of waste management and the material turn-over of society (EC, 2015). Numerous studies have documented the environmental and economic benefits of recycling, from both technological and system-level perspectives (e.g., Björklund and Finnveden, 2005; Choi et al., 2004; Laurijssen et al., 2010; Thormark, 2001; Villanueva and Wenzel, 2007). Paper is one of the most prominent materials in municipal solid waste (The World Bank, 2012), as well as the waste material fraction with the highest recycling rates, reaching $72 \%$ in Europe (CEPI, 2014) and $58 \%$ at a global level (BIR, 2012). Paper recycling saves virgin fibres and consumes less energy compared with virgin-fibre-based production (Villanueva and Wenzel, 2007). Not all paper is recycled in the same amounts: corrugated and kraft grades, as well as newspapers and magazines, constitute just over $70 \%$ of all the recovered paper in Europe (CEPI, 2014). These grades are mostly used in the production of packaging and graphic paper, which represent $68 \%$ and $23 \%$ of the total recovered paper utilization, respectively. Hence, the average recycled fibre content will range between $93 \%$ and 95 $\%$ for case materials and newsprint to just over $12 \%$ for other graphic paper (CEPI, 2014), which usually has high visual quality requirements. While paper recycling has been shown to be environmentally beneficial, it is not only the paper fibres that are reintroduced into the production cycle. Chemicals added during the original paper product manufacturing process (i.e. paper production, printing, and converting stages), and/or chemicals taken up by the paper during its use phase, will also be reintroduced into the recycling process. Recent studies have demonstrated that many of these chemicals are potentially hazardous and unwanted in the final products (Liao and 
Kannan, 2011a; Pivnenko et al., 2015a). However, very few quantitative data exist documenting the levels of these chemicals in the waste paper materials collected for recycling.

Paper is a product with certain freedom in its physical appearance and chemical composition. Paper products may incorporate a significant number of chemicals, added mainly during the printing and converting processes (i.e. binding, gluing, laminating, labelling), before the product reaches the consumer (Pivnenko et al., 2015a). Such substances may include plasticizers, binders, strengthincreasing agents, coatings, pigments, inks, solvents, etc. (Pivnenko et al., 2015a). The list of substances may increase even further during the use phase of the paper, in which chemicals may be added or taken up as a consequence of the paper products' use (e.g., use of adhesives or inks, contact with food, cleaning of surfaces, etc.). Once a paper product has become obsolete, the paper enters the waste management system: for example, it is collected either in the source-segregated or in the residual (mixed) flow of household waste. As the paper is co-disposed together with other paper and waste materials, substances may be transferred from another waste material to the paper fraction intended for recycling. Furthermore, paper as a commodity is traded on the international market, potentially posing additional challenges to the sustainable management of waste paper stream. As an example, 5.2 million tonnes of paper were imported to Europe for consumption in 2014, while almost 10 million tonnes (or $17 \%$ of the total amount collected) of waste paper were exported for recycling (CEPI, 2014). This suggests that not all waste paper materials may be equally well suited to recycling (due to the presence of unwanted chemicals), but also that the collection system itself may affect the quality of paper as a secondary raw material (Miranda et al., 2013, 2010). Concerns about the presence of potentially hazardous chemicals in paper have been voiced in the literature, mainly in relation to food consumption (Binderup et al., 2002; Lorenzini et al., 2013; Pérez-Palacios et al., 2012; Triantafyllou et al., 2007). Food-contact materials are expected to be a significant source of exposure to the chemicals present in paper (Muncke, 2009). 
This form of exposure may occur when chemicals present in packaging or other food-contact materials migrate onto the food, which is then ingested by humans (Parry and Aston, 2004; Triantafyllou et al., 2007). On the other hand, dermal exposure may also occur from handling paper contaminated with chemicals (Biedermann et al., 2010).

All food-contact materials in the European Union are subject to the general requirements set by the regulation framework (EC, 2004), which requires that materials do not: i) "release their constituents into food at levels harmful to human health"; ii) "change food composition, taste and odour in an unacceptable way”. Additionally, production of food-contact materials is covered by the EU regulations addressing "good manufacturing practices" (EC, 2006). Finally, European legislation has regulations for specific material groups coming into contact with food. Such materials include plastics (EU, 2011a), recycled plastic materials (EC, 2008), ceramics (EC, 1984), etc. Nevertheless, no specific regulations addressing paper (including recycled paper) as a food-contact material currently exist. Instead, in addition to the general food-contact regulations, food-contact paper materials are covered by the industry guidelines produced by the European paper and board food packaging chain (CEPI, 2012). A recent study (Pivnenko et al., 2015a) has outlined the chemicals of concern that could potentially be present in paper products and by extension in waste paper. It was suggested that around 10,000 different chemicals could potentially be present in paper. Of these, over 150 were identified as hazardous and requiring additional attention. Among the chemical groups identified as potentially critical for paper recycling were mineral oils, phenols, phthalates, and parabens. In order to further improve the quality of the waste paper collected for recycling, and avoid the potential re-circulation of unwanted hazardous chemicals, more detailed and quantitative information about the contents of these chemicals in actual waste paper samples is needed. 
The aim of this paper is to provide compositional data concerning selected chemicals in individual fractions of waste paper collected from households, in order to provide an improved basis for evaluating the quality and recyclability of waste paper. The specific objectives are as follows: i) to provide data concerning the detailed fractional composition of paper and board materials in Danish household waste, based on a sampling campaign; ii) to quantify the solid concentrations of selected mineral oils, phenols, phthalates, polychlorinated biphenyls, and toxic metals $(\mathrm{Cd}, \mathrm{Co}, \mathrm{Cr}, \mathrm{Cu}, \mathrm{Ni}$, and $\mathrm{Pb}$ ); iii) to evaluate potential differences, in terms of the concentration levels of these potentially hazardous chemicals, between paper fractions collected as part of the residual waste and paper fractions collected after source-segregation in households, and finally; iv) to provide recommendations with respect to the inclusion or exclusion of individual fractions in sourcesegregation schemes for paper waste from households.

\section{Materials and methods}

\subsection{Materials}

Samples of waste paper and board were collected in April 2013 from a municipality in Southern Denmark, in accordance with standard methods for solid waste sampling (Nordtest, 1995). The municipality employs a separate collection scheme for the recyclable fractions of the waste, i.e., paper, metal, glass, etc. The samples collected represented both residual and source-segregated fractions of the waste generated by 100 single-family households within the period of two weeks. The details of the sampling campaign for residual waste are described in an earlier publication (Edjabou et al., 2015). The source-segregated waste paper was collected in parallel with the residual waste, sharing both geographical and temporal scopes. The source-segregated paper was sorted by the households and placed in a two-compartment waste bin (DuoFlex ${ }^{\circledR}$, Dansk Affald, Denmark). One compartment contained recyclable packaging (plastic, glass, and metal), while the other compartment was dedicated to paper, board, and light plastic foil. The sorting guidelines provided 
by the municipality specified the individual paper and board items that should (e.g., newspapers, advertisements, magazines, folding boxes, tubes, etc.) or should not be included in the sourcesegregated flow (including paper and board packaging with food residues (e.g., pizza boxes), and milk, juice, and other beverage cartons, as well as books). The residual waste in the sample area was incinerated with energy recovery, whereas the source-segregated fractions were sent for further sorting and material recycling (outside the area). The total amount of residual and source-segregated paper samples collected was approx. $400 \mathrm{~kg}$. The total waste paper collected (both residual and source-segregated) represents all the paper and board generated from the involved households in the study area, excluding the bulkier board items commonly collected as bulky waste at recycling stations.

\subsection{Methods}

\subsubsection{Sample preparation}

After collection, the residual waste paper was manually sorted from the remaining residual household waste. Subsequently, both waste paper flows (residual and source-segregated) were sorted into more detailed fractions of paper and board, according to the physical appearance of the paper items (e.g., advertisements, corrugated boxes) and their potential use (e.g., food packaging). In total, the waste paper from each flow was sorted into 17 paper fractions, and 13 board fractions. The separation between paper and board was qualitatively based on the material thickness (paper < ca. $0.3 \mathrm{~mm} \leq$ board), since a quantitative distinction (e.g., based on mass of paper per unit of area (ISO 536:2012)) would not have been feasible for inhomogeneous samples in such large amounts. Each separate fraction was coarsely shredded (ARP SC2000, Brovst, Denmark), followed by onedimension lot splitting (Petersen et al., 2005) for sample size reduction, and fine shredding down to a particle size of $<4 \mathrm{~mm}$ (SM2000, Retsch, Germany). The finely shredded samples were 
lyophilized, placed in glass containers and stored at $-20{ }^{\circ} \mathrm{C}$ before being analysed. Schematic representation of the sample preparation procedure is provided in Figure 1.
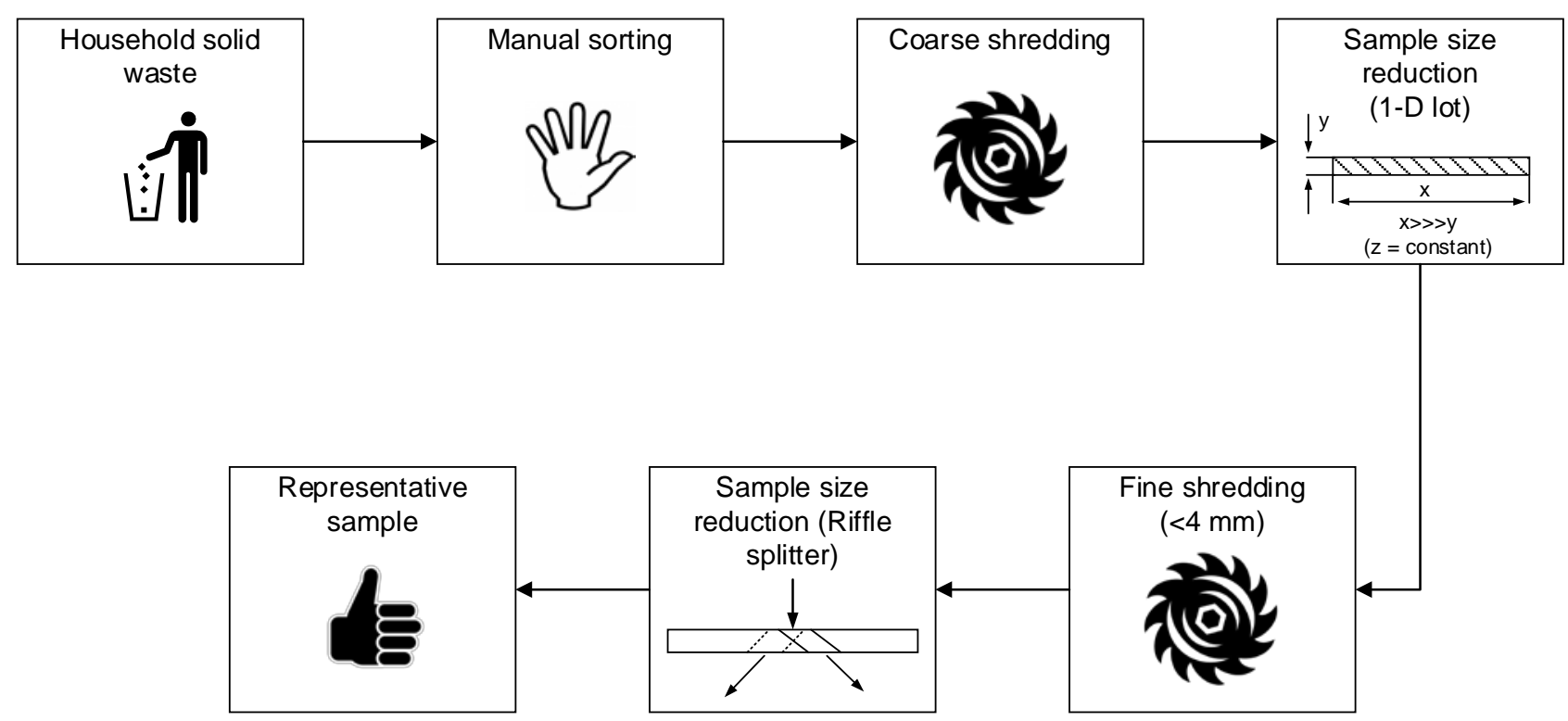

Figure 1. Schematic flowchart of sample preparation.

\subsubsection{Chemical composition}

Based on the overview of potentially critical chemicals in paper materials (Pivnenko et al., 2015a), selected groups of chemicals were analysed. These groups included mineral oils, phenols, phthalates, polychlorinated biphenyls (PCBs), and toxic metals. The overview of chemicals quantified in the study, as well as the equipment used, is presented in Table 1. Both the recoveries and the respective limits of detection (LOD) achieved for each of the chemicals, along with their CAS numbers, are provided in Tables S1-S10 (Supplementary Material). All the results presented are on a dry matter $(\mathrm{dm})$ basis.

Table 1. Chemicals quantified in the present study and the equipment used.

\begin{tabular}{lllc}
\hline$\#$ & Chemical group & Analytes & $\begin{array}{l}\text { Equipment } \\
\text { used* }\end{array}$ \\
\hline 1 & $\begin{array}{l}\text { Mineral oil } \\
\text { hydrocarbons }\end{array}$ & $n \mathrm{C}_{10}-n \mathrm{C}_{20}, n \mathrm{C}_{20}-n \mathrm{C}_{30}, n \mathrm{C}_{30}-n \mathrm{C}_{40}$ & GC-FID \\
\hline 2 & Phenols & $\begin{array}{l}\text { Nonylphenol (NP), 4-nonylphenol (4-NP), 4-chloro-3-methylphenol (4-C-3- } \\
\text { MP), 4-octylphenol (4-OP), 4-tert-octylphenol (4-t-OP), 2-phenylphenol (2- }\end{array}$ & GC-MS \\
\hline
\end{tabular}




\begin{tabular}{lllll}
\hline & & PP), and bisphenol A (BPA) & \\
\hline 3 & Phthalates & $\begin{array}{l}\text { Bis (2-ethylhexyl)phthalate (DEHP), butyl benzyl phthalate (BBP), di (2- } \\
\text { methoxyethyl) phthalate (DMEP), didecyl phthalate (DDP), dicyclohexyl } \\
\text { phthalate (DCHP), dibutyl phthalate (DBP), di-iso-butyl phthalate (DiBP), } \\
\text { didecyl phthalate (DPP), diethyl phthalate (DEP), and dimethyl phthalate } \\
\text { (DMP) }\end{array}$ & GC-MS \\
\hline 4 & $\begin{array}{l}\text { Polychlorinated } \\
\text { biphenyls }\end{array}$ & PCB-28, PCB-52, PCB-101, PCB-118, PCB-138, PCB-153, and PCB-180 & GC-MS \\
\hline 5 & Toxic metals & Cd, Co, Cr, Cu, Ni, Pb & ICP-MS \\
\hline
\end{tabular}

GC: gas chromatographer; FID: flame ionization detector; MS: mass spectrometer; ICP: inductively coupled plasma.

\section{Mineral oil hydrocarbons (MOHs)}

The mineral oils of interest were analysed as a sum parameter. Mineral oil or hydrocarbon oil index (HOI) is a parameter that quantifies the compounds extractable with an apolar hydrocarbon solvent (boiling point between $36{ }^{\circ} \mathrm{C}$ and $69{ }^{\circ} \mathrm{C}$ ) and which may be chromatographed with retention times between those of n-decane $\left(\mathrm{C}_{10} \mathrm{H}_{22}\right)$ and n-tetracontane $\left(\mathrm{C}_{40} \mathrm{H}_{82}\right)$. The chemicals complying with the above definition are mainly long-chain or branched aliphatic, alicyclic or alkyl-substituted aromatic hydrocarbons. Some natural wood extractives present in paper (e.g., fatty acids) are too polar and would not be extracted, while others (e.g., esters of fatty acids or waxes) would be removed in the clean-up step. The results were split in three fractions: the first fraction (“light fraction”) included lighter MOHs with boiling points from $175{ }^{\circ} \mathrm{C}\left(n \mathrm{C}_{10}\right)$ to $344{ }^{\circ} \mathrm{C}\left(n \mathrm{C}_{20}\right)$; the second fraction (“intermediate fraction”) included heavier MOHs with boiling points from $344{ }^{\circ} \mathrm{C}\left(n \mathrm{C}_{20}\right)$ to $450{ }^{\circ} \mathrm{C}$ $\left(n \mathrm{C}_{30}\right)$; and the final, "heavy fraction”, included $\mathrm{MOHs}$ with boiling points from $450{ }^{\circ} \mathrm{C}\left(n \mathrm{C}_{30}\right)$ to $525{ }^{\circ} \mathrm{C}\left(n \mathrm{C}_{40}\right)$. The $\mathrm{MOH}$ analysis was performed using a gas chromatograph $(\mathrm{GC})$ coupled to a flame ionization detector (FID), in accordance with a standard method (ISO/FDIS 16703) applicable to the hydrocarbon content in a solid waste matrix between 0.1 and $10 \mathrm{~g} / \mathrm{kg} \mathrm{dm}$.

Paper samples (1.5 g) were extracted using $50 \mathrm{ml}$ n-hexane for $2 \mathrm{~h}$. The $\mathrm{n}$-hexane contained $1 \mathrm{mg} / \mathrm{l}$ n-decane and $2 \mathrm{mg} / \mathrm{l}$ n-tetracontane as GC retention time markers. Prior to the solid-phase extraction (SPE) clean-up, anhydrous $\mathrm{Na}_{2} \mathrm{SO}_{4}$ was added to the extracts. Commercially available cartridges containing $2 \mathrm{~g}$ of Florisil and $2 \mathrm{~g}$ of $\mathrm{Na}_{2} \mathrm{SO}_{4}$ were used for the clean-up. The columns 
were equilibrated using $10 \mathrm{ml}$ n-hexane before the extracts were passed through. The extracts were analysed using an Agilent 6980 GC-FID (Agilent Technologies, Santa Clara, USA). Chromatographic separation was achieved on a $30 \mathrm{~m}$ x $0.25 \mathrm{~mm}$ x $0.1 \mu \mathrm{m}$ Zebron ZB-5 capillary column (Phenomenex, Torrance, USA). The $1 \mu \mathrm{l}$ sample was injected in splitless mode at $280{ }^{\circ} \mathrm{C}$. The initial temperature of $35^{\circ} \mathrm{C}$ was held for $3 \mathrm{~min}$ and the oven was ramped at $20^{\circ} \mathrm{C} / \mathrm{min}$ from 35 to $350{ }^{\circ} \mathrm{C}$ and held for $5 \mathrm{~min}$. Helium was used as a carrier gas at a $1 \mathrm{ml} / \mathrm{min}$ constant flow rate and the FID was operated at $380{ }^{\circ} \mathrm{C}$. Certified oil mixture (diesel fuel/lubricating oil (1:1), BAM-K010e (BAM, Berlin, Germany)) was used for control and calibration purposes. The achieved LOD was 80 $\mathrm{mg} / \mathrm{kg} \mathrm{dm}$, and replicates of a single sample resulted in a relative standard deviation (RSD) that ranged from $12 \%$ (for the heavy fraction) to $32 \%$ (for the light fraction).

\section{Phenols}

Selected phenols (see Table 1 for details) were extracted by microwave-assisted extraction (MAE). The MAE (Multiwave 3000, Anton-Paar, Graz, Austria), solid-phase extraction, derivatization and GC-MS analysis of selected phenols were based on methods described by Alonso et al. (1998) and Morales et al. (2005). Two grams of paper samples were extracted by MAE (Multiwave 3000, Anton-Paar, Graz, Austria) using $30 \mathrm{ml}$ methanol/Milli-Q water/triethylamine (78:20:2) as a solvent, at $120^{\circ} \mathrm{C}$ and approx. 4 bar for $40 \mathrm{~min}$. Following this, $70 \mathrm{ml}$ acidified Milli-Q water $(\mathrm{pH}<$ 2) was added to the extracts prior to filtration with a $0.45 \mu \mathrm{m}$ syringe filter. The samples were applied to an OASIS HLB SPE column (6 ml, 1 g, Waters Corp., Milford, USA), conditioned with $6 \mathrm{ml}$ methanol and $6 \mathrm{ml}$ acidified Milli-Q water. The columns were dried by lyophilization and eluted using $6 \mathrm{ml}$ ethyl acetate. The samples were further subjected to SPE clean-up using LCFlorisil columns (Supelco, St. Louis, USA), conditioned with ethyl acetate, before being evaporated to dryness. Then, $50 \mu \mathrm{l}$ BSTFA:TMCS (99:1) and $10 \mu \mathrm{l}$ pyridine (anhydrous) were added and derivatization was achieved at $70{ }^{\circ} \mathrm{C}$ for $1 \mathrm{~h}$, prior to GC-MS analysis. For this, $100 \mu \mathrm{g} / \mathrm{l}$ Bisphenol 
A-d16 and 4-tert-octylphenol-ring-13C6 were used as internal standards. Chromatographic separation was achieved on an Agilent 6890 gas chromatograph (Agilent Technologies, Santa Clara, USA) equipped with a $30 \mathrm{~m}$ x $0.25 \mathrm{~mm}$ i.d. x $1 \mu \mathrm{m}$ film thickness HP-5ms column (Agilent Technologies, Santa Clara, USA), with the oven programmed to $80^{\circ} \mathrm{C}$ for $1 \mathrm{~min}$, then ramped at 10 ${ }^{\circ} \mathrm{C} / \mathrm{min}$ to $300{ }^{\circ} \mathrm{C}$ and held for $2 \mathrm{~min}$. Detection was achieved on an Agilent 5975C triple-axis massselective detector (Agilent Technologies, Santa Clara, USA), operated in selected ion monitoring (SIM) mode, with the MS source at $230^{\circ} \mathrm{C}$ and the quadrupole at $150{ }^{\circ} \mathrm{C}$. The detection limits ranged from $0.012 \mathrm{mg} / \mathrm{kg}$ to $0.79 \mathrm{mg} / \mathrm{kg}$ for 4-NP, 4-OP, 4-t-OP, and NP, respectively (see Tables S3 and S4 (Supplementary Material) for details). All samples were analysed in single, while replicates of a random sample resulted in an RSD that ranged between 1 \% (4-t-OP) and 63 \% (4-c3-MP).

\section{Phthalates}

The phthalates covered in this study (see Table 1 for details) were extracted and analysed based on the CEN/TC 308 and EPA 8061A standard methods. In brief, $2 \mathrm{~g}$ samples were extracted in Erlenmeyer flasks using $20 \mathrm{ml}$ ethyl acetate. The samples were shaken gently for $12 \mathrm{~h}$ at room temperature. The extracts were subjected to SPE clean-up using Alumina-N columns (Supelco, St. Louis, USA), conditioned with ethyl acetate, and evaporated to approx. $500 \mu$ prior to GC-MS analysis. For this, $25 \mu \mathrm{g} / 1$ DMP-d4 and DEHP-d4 were used as internal standards. Chromatographic separation was achieved on an Agilent 6890 gas chromatograph (Agilent Technologies, Santa Clara, USA), equipped with a $60 \mathrm{~m}$ x $0.25 \mathrm{~mm}$ i.d. x $0.25 \mu \mathrm{m}$ film thickness ZB-5ms column with a $5 \mathrm{~m}$ guard column (Phenomenex, Torrance, USA). The samples were injected in splitless mode with the sample inlet held at $300{ }^{\circ} \mathrm{C}$. The oven was programmed to $70{ }^{\circ} \mathrm{C}$ for $3 \mathrm{~min}$, then ramped at 13 ${ }^{\circ} \mathrm{C} / \mathrm{min}$ to $270{ }^{\circ} \mathrm{C}$, then at $50{ }^{\circ} \mathrm{C} / \mathrm{min}$ to $300{ }^{\circ} \mathrm{C}$ and finally held for $12 \mathrm{~min}$. Helium was used as a carrier gas with a $1 \mathrm{ml} / \mathrm{min}$ constant flow. The mass detector settings were as above. The detection 
limits ranged from 0.012 to $2.5 \mathrm{mg} / \mathrm{kg} \mathrm{dm}$ for DCHP and DEHP, respectively (see Tables S5 and S6 (Supplementary Material) for details). A single sample analysed in replicates resulted in an RSD that ranged from $4 \%$ to $38 \%$ for DBP and BBP, respectively.

\section{Polychlorinated biphenyls (PCBs)}

Analysing all the possible PCB congeners (209) would be technically challenging and time consuming. A commonly used list of six indicator PCBs (28, 52, 101, 138, 153 and 180), referred to as "PCB 6 ", has been proposed by the German Institute for Standardization (DIN 51527-1). This list covers PCBs with high concentrations in technical mixtures and a wide range of chlorine atoms (from three to seven chlorine atoms per PCB molecule). The list, expanded to include the 118 congener ("PCB $\mathrm{P}_{7}$ "), is generally used in the EU for the analysis of PCBs in environmental and food samples (Sundhedsstyrelsen, 2013). The extraction and analysis of the seven selected PCB congeners (see Table 1 for details) were performed in accordance with EPA 3546 standard method. Two grams of paper samples were extracted by MAE (Multiwave 3000, Anton-Paar, Graz, Austria) using 30 n-hexane at $120{ }^{\circ} \mathrm{C}$ and approx. 4 bar for 40 min. The extracts were subjected to SPE clean-up using LC-Florisil columns (Supelco, St. Louis, USA), conditioned with n-hexane, and evaporated to approx. $100 \mu \mathrm{l}$, prior to GC-MS analysis. For this, $10 \mu \mathrm{g} / 1 \mathrm{l}, 2,3,4$ tetrachloronaphthalene was used as an internal standard and 2,2,4-trimethyl pentane as a keeper.

GC-MS analysis was performed as above but with the oven programmed to $80{ }^{\circ} \mathrm{C}$ for $1 \mathrm{~min}$, then ramped at $5{ }^{\circ} \mathrm{C} / \mathrm{min}$ to $170{ }^{\circ} \mathrm{C}$, then $2{ }^{\circ} \mathrm{C} / \mathrm{min}$ to $250{ }^{\circ} \mathrm{C}$, then $10^{\circ} \mathrm{C} / \mathrm{min}$ to $280{ }^{\circ} \mathrm{C}$, and finally held for $13 \mathrm{~min}$. The mass detector settings were the same as in the phenols and phthalates analyses. The achieved LOD was $0.33 \mu \mathrm{g} / \mathrm{kg}$ dm for each of the PCB constituents. Replicates of a single sample showed RSDs ranging between $21 \%$ for PCB-52 and PCB-101, and $31 \%$ for PCB-153.

\section{Toxic metals}


The analysis of selected toxic metals (see Table 1 for details) was performed in accordance with the US EPA Method 3051a. In brief, 0.25 g of waste paper was digested by microwave-assisted digestion (Multiwave 3000, Anton-Paar, Graz, Austria) using $10 \mathrm{ml} \mathrm{HNO}_{3}$. The temperature was ramped to $175^{\circ} \mathrm{C}$ for $5.5 \mathrm{~min}$ and held for $4.4 \mathrm{~min}$. The resulting digestates were diluted in Milli-Q water before analysis by ICP-MS (7700x, Agilent Technologies, Santa Clara, USA). The LODs achieved were between 0.039 and $0.38 \mathrm{mg} / \mathrm{kg} \mathrm{dm}$ for Co and Cr, respectively (see Tables S9 and S10 (Supplementary Material) for details). Each digestate was analysed in triplicate, resulting in RSDs ranging from $6 \%$ for Ni to $24 \%$ for Cd.

\subsubsection{Data handling and calculations}

The limits of detection for each of the chemicals were calculated as an average of the analysed blanks plus three standard deviations of the blank. When no signal could be quantified in the blanks, the LOD was calculated as the lowest calibration standard plus three standard deviations of the standard. Blanks and standards were processed using the same extraction and clean-up steps as the samples. For the calculation of sum, mean, or median values, values below the limit of detection were substituted by $65 \%$ of the respective limit of detection, as suggested by Martín-Fernández et al. (2003). The weighted concentrations (i.e., taking into account the fractional composition of waste paper) of chemicals in the residual and source-segregated waste paper flows were compared by means of the Student's $t$-test. The null hypothesis was that the true difference in mean values would be equal to zero, i.e. there is no difference in the concentration of chemicals between residual and source-segregated waste paper fractions. Assuming a $95 \%$ confidence interval, the null hypothesis can be rejected for $p$-values $<0.05$. The normality of data distribution was assured through log-transformation whenever necessary (Reimann et al., 2008). To visualize the difference between concentrations of chemicals in residual and source-segregated paper, box plots are provided in the results and discussion section. The box plots present data as a five-point summary: 
the minimum, lower quartile $\left(25^{\text {th }}\right.$ percentile), median $\left(50^{\text {th }}\right.$ percentile), upper quartile $\left(75^{\text {th }}\right.$ percentile), and maximum (Kabacoff, 2011).

\section{Results and discussion}

\subsection{Fractional composition of waste paper}

Table 2 presents the relative composition of paper and board in the residual and source-segregated waste flows, as well as in the combination of the two flows. Of the total waste paper and board collected, $21 \%$ was from residual waste, while the remaining $79 \%$ was recovered as sourcesegregated waste flow. The bulk of the total waste paper and board (72 \%) came from advertisements, newspapers, and magazines. Most of these paper products were part of the sourcesegregated waste paper, as the municipality’s sorting guide specifies newspaper, magazines, advertisements, phone books, office paper, and envelopes as the waste paper items intended for separate collection and recycling. These fractions are expected to account for the highest consumption of paper in an average household, since graphic paper represents $38 \%$ of the total paper consumed in Europe (CEPI, 2014). Advertising material accounts for approx. $48 \%$ of the total paper and board waste collected for this study, a figure significantly higher than the $23 \%$ and $25 \%$ reported in the literature (Riber et al., 2009; Salhofer et al., 2008). The difference is mainly the result of discrepancies in flow definitions between this study and the literature. The present study takes into account the waste paper generated at household level, but excludes bulky board items discarded at recycling stations. A recent study estimated that an average Danish household annually receives $55 \mathrm{~kg}$ of unsolicited mail, of which the majority is advertisements (Sanchez and Møller, 2011). On the other hand, the main fractions in the residual waste were office paper, beverage cartons, and newspapers. Fractions of waste board (F18-F30, Table 2) accounted for almost $13 \%$ of the source-segregated paper flow. In contrast, board in the residual waste paper accounted for more than $43 \%$ of the flow. Most board items not sorted into a separate waste stream 
end up in the residual waste, either due to contamination from use (e.g., food packaging) or as a result of non-existent recycling schemes (e.g., beverage cartons).

Table 2. Composition of residual and source-segregated waste paper and board (\% wet weight). Residual and source-segregated flows contributed with $21 \%$ and $79 \%$ of the total sample collected, respectively.

\begin{tabular}{|c|c|c|c|c|c|}
\hline & $\#$ & Fractions & $\begin{array}{c}\text { Residual } \\
{[\%]}\end{array}$ & $\begin{array}{c}\text { Source-segregated } \\
{[\%]}\end{array}$ & $\begin{array}{c}\text { Total } \\
{[\%]}\end{array}$ \\
\hline \multirow{18}{*}{ Paper } & F1 & Advertisements (non-glued) & 7.9 & 28.1 & 23.8 \\
\hline & F2 & Advertisements (glued) & 4.4 & 20.1 & 16.8 \\
\hline & F3 & Newsprint advertisements (non-glued) & 2.7 & 5.0 & 4.5 \\
\hline & F4 & Newsprint advertisements (glued) & 1.6 & 3.0 & 2.7 \\
\hline & F5 & Newspapers & 9.8 & 17.2 & 15.6 \\
\hline & F6 & Magazines, Journals, TV guides (non-glued) & 3.8 & 6.5 & 6.0 \\
\hline & F7 & Magazines, Journals, TV guides (glued) & 1.5 & 3.0 & 2.7 \\
\hline & F8 & Office and administrative paper & 12.9 & 3.0 & 5.1 \\
\hline & F9 & Envelopes & 2.5 & 0.4 & 0.9 \\
\hline & F10 & Wrapping paper & 0.9 & 0.1 & 0.3 \\
\hline & F11 & Receipts & 0.7 & $<0.1$ & 0.1 \\
\hline & F12 & Self adhesives & 0.1 & $<0.1$ & $<0.1$ \\
\hline & F13 & Books and booklets & 2.0 & 0.7 & 1.0 \\
\hline & F14 & Phonebooks & 0.4 & 0.0 & 0.1 \\
\hline & F15 & Tissue paper & 0.9 & $<0.1$ & 0.2 \\
\hline & F16 & Kraft paper (brown and bleached) & 2.1 & 0.2 & 0.6 \\
\hline & F17 & Other paper $^{1}$ & 2.2 & 0.1 & 0.5 \\
\hline & & Total paper & 56.6 & 87.3 & 80.8 \\
\hline \multirow[t]{15}{*}{ Board } & F18 & Corrugated boxes - shipping & 1.7 & 1.2 & 1.3 \\
\hline & F19 & Corrugated boxes - sales (Food packaging) & 4.1 & 4.1 & 4.1 \\
\hline & F20 & Corrugated boxes - sales (Non-food packaging) & 0.8 & 2.9 & 2.5 \\
\hline & F21 & Folding boxes - shipping & 0.0 & 0.0 & 0.0 \\
\hline & F22 & Folding boxes - sales (Food packaging) & 8.9 & 2.0 & 3.5 \\
\hline & F23 & Folding boxes - sales (Non-food packaging) & 5.7 & 0.9 & 1.9 \\
\hline & F24 & Egg trays and alike & 1.2 & 0.3 & 0.5 \\
\hline & F25 & Tubes & 4.5 & 0.2 & 1.1 \\
\hline & F26 & Beverage cartons & 11.9 & 0.2 & 2.7 \\
\hline & F27 & Paper plates and cups & 0.5 & $<0.1$ & 0.1 \\
\hline & F28 & Composites $^{2}$ & 0.5 & 0.1 & 0.2 \\
\hline & F29 & Cards and labels & 1.7 & 0.3 & 0.6 \\
\hline & F30 & Other cardboard $^{1}$ & 1.9 & 0.3 & 0.6 \\
\hline & & Total board & 43.4 & 12.7 & 19.2 \\
\hline & & Total & 100 & 100 & 100 \\
\hline
\end{tabular}

${ }^{1}$ Includes articles of paper and board not covered by the fractions F1-F16 for paper, and F18-F29 for board (e.g., greaseproof and baking paper); ${ }^{2}$ Includes predominantly articles of board laminated with aluminum or plastics and not included in the remaining board fractions (e.g., Pringles ${ }^{\circledR}$ potato-based snack packaging). 


\subsection{Chemical composition}

Figure 2 presents the concentration ranges (min-max) of the analysed chemicals. The figure covers concentration ranges in both residual and source-segregated waste paper, as well as the median values found. The results for each group of chemicals are discussed in detail in the following paragraphs (3.2.1-3.2.5), while Paragraph 3.2.6 addresses the differences in chemical content between the residual and source-segregated waste paper flows. Further details on the concentrations measured are provided in Figure 3 and the Supplementary Material (Tables S1-S10).

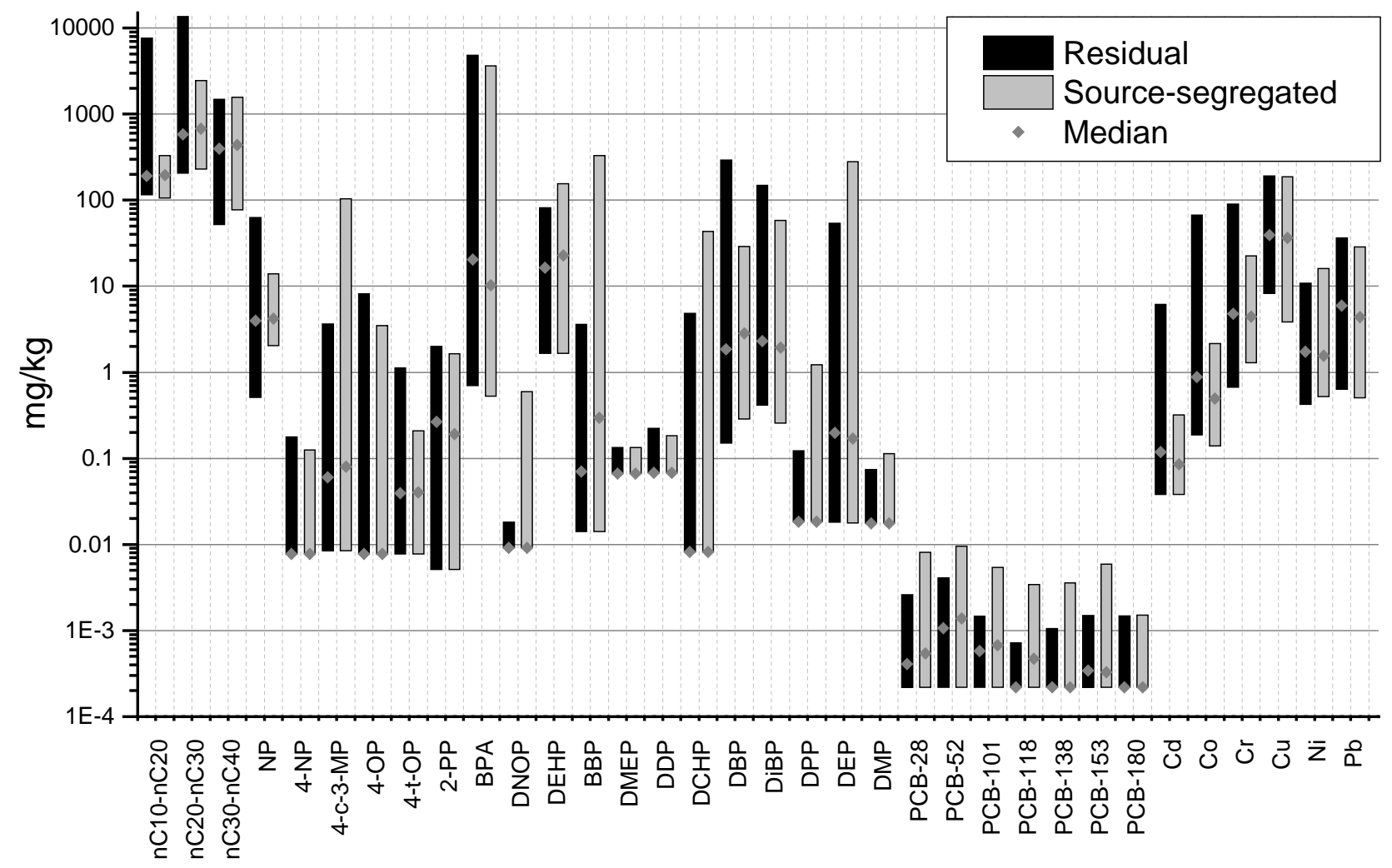

Figure 2. Concentration ranges (min-max) and median concentrations (logarithmic scale) of chemicals analysed in the present study in residual and source-segregated waste paper $(\mathrm{mg} / \mathrm{kg} \mathrm{dm})$. 


\subsubsection{Mineral oil hydrocarbons (MOHs)}

The presence of mineral oils in paper can be associated with a variety of sources, from solvents used in the paper printing and converting processes to lubricants and cleaning agents in the machinery employed (EFSA, 2012; Miljøstyrelsen, 2011). The mineral oil solvents used in paper printing mainly derive from inks, which can include between $20 \%$ and $30 \%$ mineral oil content (Droz and Grob, 1997). The concentrations of MOHs in the waste paper samples are presented in Figure 3(A) (detailed data are provided in Tables S1 and S2 (Supplementary Material)). On average, the intermediate mineral oils $\left(n \mathrm{C}_{20}-n \mathrm{C}_{30}\right)$ were present in higher concentrations when compared to the lighter and heavier fractions, $n \mathrm{C}_{10}-n \mathrm{C}_{20}$ and $n \mathrm{C}_{30}-n \mathrm{C}_{40}$, respectively (Tables $\mathrm{S} 1$ and S2 (Supplementary Material)). The mineral oils present in recycled board were shown to range from $n \mathrm{C}_{12}$ to $n \mathrm{C}_{50}$, while the mineral oils from printing inks range between $n \mathrm{C}_{13}$ and $n \mathrm{C}_{30}$ (Biedermann and Grob, 2010) and centre at $n \mathrm{C}_{18 / 19}$ (Lorenzini et al., 2010). Nevertheless, lighter mineral oils $\left(<n C_{24}\right)$ are susceptible to volatilization (Lorenzini et al., 2010), explaining their relatively lower concentrations in the analysed samples. Previous studies have identified newspapers as the main potential source of mineral oils in the waste paper flows (Biedermann and Grob, 2010; BMELV, 2012). Newspapers contained MOHs at 2,300 and 1,700 mg/kg for residual and source-segregated waste paper, respectively. These values are comparable to the range, between 180 and 8,900 mg/kg, presented in the literature (Biedermann and Grob, 2010). Besides newspapers, high concentrations of mineral oils were also found in other paper, tissue paper, tubes, and self adhesives. Other paper from the residual waste paper flow contained a concentration almost an order of magnitude higher $(22,000 \mathrm{mg} / \mathrm{kg})$ when compared to the remaining fractions. The use of waxes and glues based on mineral oils (Biedermann and Grob, 2012) could potentially explain the mineral oil content in tubes and self adhesives, respectively. At the same time, presence of mineral oils in tissue paper and other paper may potentially be related to the use phases of these materials. 

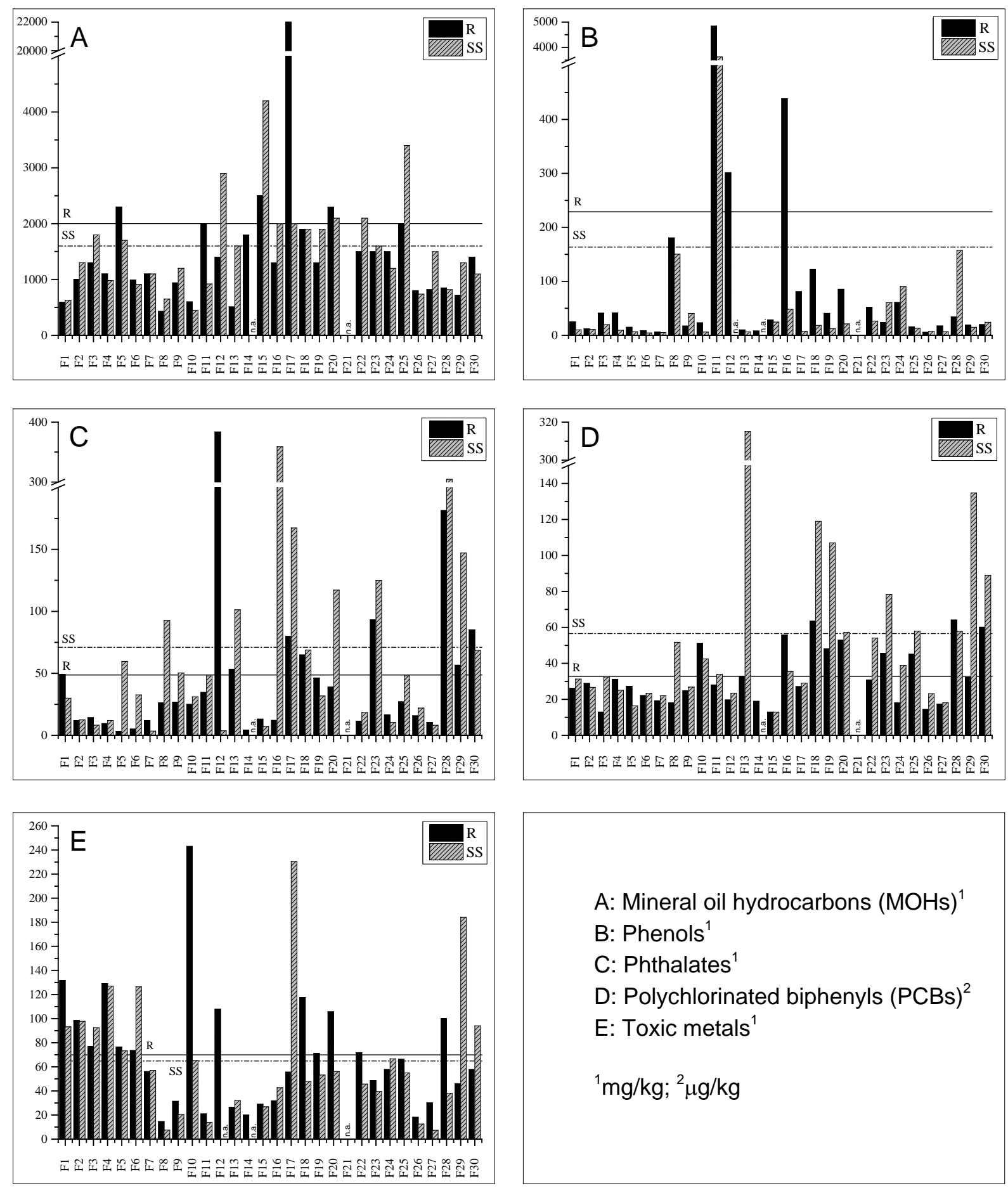

Figure 3. Total concentrations of chemicals in focus. Horizontal lines indicate the mean concentrations. R: residual waste paper; SS: source-segregated waste paper. 


\subsubsection{Phenols}

Phenols have a variety of applications in paper product manufacturing. They can be used as additives in thermal paper, as polymeric resin components, as surfactants in printing, etc. (Pivnenko et al., 2015a). All the analysed phenols showed endocrine-disrupting properties (Pivnenko et al., 2015a). By far the most significant application of phenolic compounds is in thermal paper production, where phenol-based chemicals are commonly employed as colour developers. Thermal paper is largely used in point-of-sale cashier receipts in concentrations of up to $3.2 \%$ of the paper weight (Östberg and Noaksson, 2010). Not surprisingly, the receipts fraction contained the highest amount of phenols. This was largely associated with the presence of BPA (Tables S3 and S4 (Supplementary Material)): a developer commonly employed in thermal paper (Pivnenko et al., 2015b). Further details on the presence of BPA and its structural analogues, in thermal paper receipts and in a subset of the waste paper fractions analysed in this study, can be found in an earlier publication (Pivnenko et al., 2015b). BPA was the only phenol-based chemical detected in all the samples, in concentrations ranging between 0.53 and $4,800 \mathrm{mg} / \mathrm{kg}$. Since in paper industry BPA is only used in specialty paper, its presence in all the analysed waste paper samples could indicate the spreading of this chemical through paper recycling. Similarly, earlier studies have pointed to the potential spreading of BPA between paper products as a result of paper recycling (Liao and Kannan, 2011a, 2011b).

Although the marketing and use of NP and its ethoxylates in pulp and paper production have been banned in the EU from 2005 (EC, 2003), NP was identified in almost all the samples analysed (ranging from $<0.79$ to $63 \mathrm{mg} / \mathrm{kg}$ ). This could be the result of the presence of residual $\mathrm{NP}$ potentially used in surfactant formulations in the printing industry (Miljøstyrelsen, 2011). Both NP and octylphenol are common pollutants detected in process wastewater from paper recycling (Latorre et al., 2005). The median concentrations of NP in both residual and source-segregated 
waste paper in our study (3.9 and $4.2 \mathrm{mg} / \mathrm{kg}$ ) were lower than the concentrations found in toilet paper (between 14.3 and $68.9 \mathrm{mg} / \mathrm{kg}$ ), but higher than the concentrations found in German waste paper, which ranged between 0.40 and $1.01 \mathrm{mg} / \mathrm{kg}$ (Gehring et al., 2004). However, although 4-NP has been identified as the main constituent of the technical NP mixtures (Eganhouse et al., 2009), relatively low concentrations of $4-\mathrm{NP}$ (up to $0.18 \mathrm{mg} / \mathrm{kg}$ ) were quantified in $38 \%$ and $19 \%$ of the residual and source-segregated waste paper fractions, respectively.

\subsubsection{Phthalates}

Phthalates are mainly used as plasticizers in a variety of materials and applications. Although phthalates have repeatedly been reported to have negative health impact - mainly related to their being endocrine disrupting agents — they still dominate the plasticizers market (Schossler et al., 2011). Concerns have been expressed especially regarding the lightest phthalate molecules (the most common being DEHP, BBP, DBP, and DiBP), as they have a greater potential to be released and to migrate from the host materials. These so-called "low" phthalates have been banned in the EU in toys and childcare items (EC, 2005). They were also phased out for the remainder of applications in February 2015, unless authorization had been granted for a specific use (EU, 2011b).

Gärtner et al. (2009) found that paperboard food packaging contained DiBP, DBP, BBP and DEHP. Selected phthalates, namely DiBP, DBP, and DEHP, were found in almost all the samples analysed in the present study. DiBP and DEHP were found in relatively high concentrations ranging from $<0.26$ to $160 \mathrm{mg} / \mathrm{kg}$, with DEHP quantified in the highest median concentrations: 15 and $23 \mathrm{mg} / \mathrm{kg}$ for residual and source-segregated waste paper, respectively. Similarly, a study conducted by Poças et al. (2010) found phthalates in all paper samples used for food packaging, with DiBP in the highest concentrations (up to $21 \mathrm{mg} / \mathrm{kg}$ ). 
The highest total phthalate concentrations were found in self adhesives (380 mg/kg), kraft paper (360 mg/kg) and composites (300 mg/kg) (Tables S5 and S6 (Supplementary Material)). Relatively highest concentrations were found for DBP, DIBP, and DEP, which are all commonly used as additives in adhesives (National Research Council, 2008; US EPA, 2010). On the other hand, use of BBP-rich inks (Pivnenko et al., 2015a) or high-strength label printing (involving more than $0.1 \%$ w/w of BBP (e.g., MACTac, 2013)) can be done on kraft paper..

DMEP was not detected in any of the samples analysed, while several other phthalates (DDP, DCHP, DPP, and DNOP) were only detected in a few fractions (less than $30 \%$ of the samples).Comparison of total phthalate content (Figure 3(C)) between food (F19 and F22) and nonfood packaging board (F20 and F23) revealed higher concentrations in the latter, suggesting limited use of phthalates or recycled fibre in food-packaging board. Migration from packaging onto food represents an important source for human exposure to phthalates (Fromme, 2011). This is mostly due to the presence of DEHP, DBP, and BBP, with the latter being found in concentrations of up to $330 \mathrm{mg} / \mathrm{kg}$ (Table S6 (Supplementary Material)). Phthalates have been shown to migrate rapidly from paper packaging onto food, with $20 \%$ to $40 \%$ of the initial concentration of some phthalates being transferred (Summerfield and Cooper, 2001).

\subsubsection{Polychlorinated biphenyls (PCBs)}

Polychlorinated biphenyls (PCBs) were previously used in a variety of applications. In view of potential human contact and release potential, the uses of PCBs are commonly differentiated in terms of closed and open applications. The main bulk of PCBs produced were used in closed applications, e.g., in electrical transformers, as hydraulic liquid, lubricants, etc. (US EPA, 1976). Although the USA, the largest producer of PCBs at a global level, banned their production in 1977 (Breivik et al., 2007) — followed by the rest of the world by 1993 (Breivik et al., 2007) — their 
extreme physical and chemical inertness (thermal stability, non-flammability, low water solubility, etc.) (Hutzinger et al., 1974) has allowed them to persist in the environment and to be detected even today in a variety of environmental matrices (Dömötörová et al., 2012; Hermanson and Johnson, 2007; Kassa and Bisesi, 2001). The main open application for PCBs was in carbonless copy paper, as a carrier for the ink in the ink capsules (US EPA, 1977). Such paper contained between $2 \%$ and $6 \%$ PCBs by weight (Voogt et al., 1984), and accounted for 20,000 tonnes or $3 \%$ of the total PCBs produced in the USA between 1930 and 1975 (Erickson and Kaley, 2011). Upon recycling, the ink capsules would burst and the PCBs would be released; once the fibres were processed, the PCBs could then be transferred into the newly manufactured paper products (US EPA, 1977).

Aroclor (formerly manufactured by Monsanto Co., St Luis, MO, USA) is one of the most commonly known commercial names for PCB mixtures. Aroclor name is accompanied by a fourdigit suffix, denoting the number of carbon atoms in the phenyl rings (first two digits) and massbased chlorine content (last two digits). The mixture of PCBs most commonly used in carbonless copy paper was Aroclor 1242, which included a $42 \%$ chlorine content (Albro and Parker, 1979; US EPA, 1976). Other minor applications of PCBs in paper included the use of Aroclor 1254 in paper inks and other additives (US EPA, 1976). Aroclor 1242 contained $11.9 \%$ PCB $_{7}$ (Frame et al., 1996), resulting in a correction factor of 8.4 when extrapolating from $\mathrm{PCB}_{7}$ to $\mathrm{PCB}_{\text {total }}$ concentration. This factor is close to the range of 2.5 to 8.1 commonly used when estimating the total PCB concentration based on the $\mathrm{PCB}_{7}$ indicator (Sundhedsstyrelsen, 2013).

Of the seven target PCBs, the congeners that were identified in almost all samples were PCB-52 and PCB-101 (Tables S7 and S8 (Supplementary Material)), while the heaviest congener (PCB180) was only identified in one and four samples of residual and source-segregated paper, respectively. This congener distribution can be related to the composition of Aroclor 1242, the bulk of which is represented by lighter congeners, i.e., approx. below PCB-75 (Frame et al., 1996). On 
the other hand, the relatively high frequency of detection (> $50 \%$ of the samples) for PCB-153 can potentially be attributed to the presence of Aroclor 1254, of which PCB-153 is an important constituent. The fraction with by far the highest concentrations of PCBs was F13 (books and booklets) from the source-segregated paper flow, which contained up to $320 \mu \mathrm{g} / \mathrm{kg}$ (Table S8 (Supplementary Material)). This was related to the fact that, in the source-segregated flow, the fraction contained mainly books, while the residual fraction contained mainly booklets. The lifespan of books is expected to be significantly longer than that of booklets (Cote et al., 2014), resulting in a greater potential for PCBs to be present. Additionally, board fractions (F18-F30) presented higher concentrations of PCBs than paper fractions (F1-F17). The $\mathrm{PCB}_{7}$ median values of 3.3 and 4.1 $\mu \mathrm{g} / \mathrm{kg}$ correspond well to the range $(1.5-5.0 \mu \mathrm{g} / \mathrm{kg})$ presented by Binderup et al. (2002) for 16 congeners analysed in paper samples obtained from the paper industry; nevertheless, the authors characterized these levels as low and insignificantly different from the background concentrations. Values for $\mathrm{PCB}_{6}$ were in the range of $1.3-7.3 \mu \mathrm{g} / \mathrm{kg}$ and $1.3-34 \mu \mathrm{g} / \mathrm{kg}$ for residual and sourcesegregated flows, respectively. For comparison, European legislation allows concentrations of PCB $_{6}$ in selected foodstuffs to be as high as $300 \mu \mathrm{g} / \mathrm{kg}$, while food fed to young children should not contain more than $1 \mu \mathrm{g} / \mathrm{kg}$ of $\mathrm{PCB}_{6}$ (EC, 2011).

\subsubsection{Toxic metals}

The presence of metals in paper can be attributed to the natural presence of metals in wood (Algreen et al., 2012), metals added as part of inks, pigment preparation, and coatings or impurities (Pivnenko et al., 2015a). Concentration of metals naturally occurring in wood may vary depending on plant species, part of plant used in paper making, and local soil conditions (McLaughlin et al., 2011). Presence of metals in some of the analysed samples could be explained by metals contained in wood, as typical concentration ranges are $0.05-0.5 \mathrm{mg} / \mathrm{kg}, 0.03-10 \mathrm{mg} / \mathrm{kg}, 1.6-14 \mathrm{mg} / \mathrm{kg}$, and 0.3 - $5.3 \mathrm{mg} / \mathrm{kg}$ for $\mathrm{Cd}, \mathrm{Cr}, \mathrm{Cu}$, and $\mathrm{Ni}$, respectively (Algreen et al., 2013, 2012). Among the 
potentially toxic metals analysed in this study, $\mathrm{Cu}$ showed the highest median and maximum concentrations in both residual and source-segregated waste paper. In both flows, the highest concentration was $190 \mathrm{mg} / \mathrm{kg}$ in wrapping and other paper, respectively. Interestingly, fractions of printed periodicals (F1-F5, see Table 2 for details), showed elevated Cu concentrations (> 50 $\mathrm{mg} / \mathrm{kg}$ ) suggesting printing inks as potential source of $\mathrm{Cu}$. An earlier study on chemicals in paper handkerchiefs and toilet paper also observed higher concentrations of $\mathrm{Cu}$ in articles with colour decorations (Miljøstyrelsen, 2003). Additionally, $\mathrm{Cr}$ and $\mathrm{Pb}$ were found in high median concentrations (Tables S9 and S10 (Supplementary Material)). The self adhesives fraction of the residual waste paper contained Cr concentrations (90 mg/kg) well above the median value of all the fractions $(4.8 \mathrm{mg} / \mathrm{kg})$, potentially due to the attachment of fine particles of materials containing $\mathrm{Cr}$ to the adhesive part of the paper. Nevertheless, the values were still within the concentration ranges found in the literature (Pivnenko et al., 2015a). In both residual and source-segregated waste paper, $\mathrm{Pb}$ was found in slightly higher concentrations (from $<0.056$ to $36 \mathrm{mg} / \mathrm{kg}$ ) when compared to older studies from Denmark (from 0.65 to $12 \mathrm{mg} / \mathrm{kg}$ ) (Riber et al., 2009), or when compared to Rotter et al. (2004), in which $\mathrm{Pb}$ amounted to $23 \pm 9 \mathrm{mg} / \mathrm{kg}$ in paper and board from German household waste. These values can be higher than the limit of $3.0 \mathrm{mg} / \mathrm{kg}$ for $\mathrm{Pb}$ in food-contact paper and board as set by the European paper industry guideline (CEPI, 2012).

Among the remaining toxic metals, the highest concentrations for $\mathrm{Cd}$, Co, and Ni were found in board composites (6.1 mg/kg), shipping corrugated boxes (67 mg/kg), and other paper (16 mg/kg), respectively. Presence of Co in corrugated boxes can be result of packaging ink raw material that can potentially contain cobalt acetate, carbonate, or sulphate (Pivnenko et al., 2015a). In case recycled board composites are to be used in food-contact material production, content of Cd may be of concern as it was more than tenfold higher than the established limit of $0.5 \mathrm{mg} / \mathrm{kg}$ (CEPI, 2012).

\subsubsection{Residual versus source-segregated waste paper}


Box plots of the total concentrations of the abovementioned groups of chemicals in residual and source-segregated waste paper and board flows are presented in Figure 4. Each point represents cumulated concentrations of the chemical groups discussed above for each of the fractions in residual and source-segregated waste paper. The cumulated concentrations were multiplied by the respective shares of residual or source-segregated waste paper composition, in order to derive weighted concentrations. As evident from Figure 4, the concentrations of chemicals in the sourcesegregated flow show larger variations and are skewed towards lower values when compared to

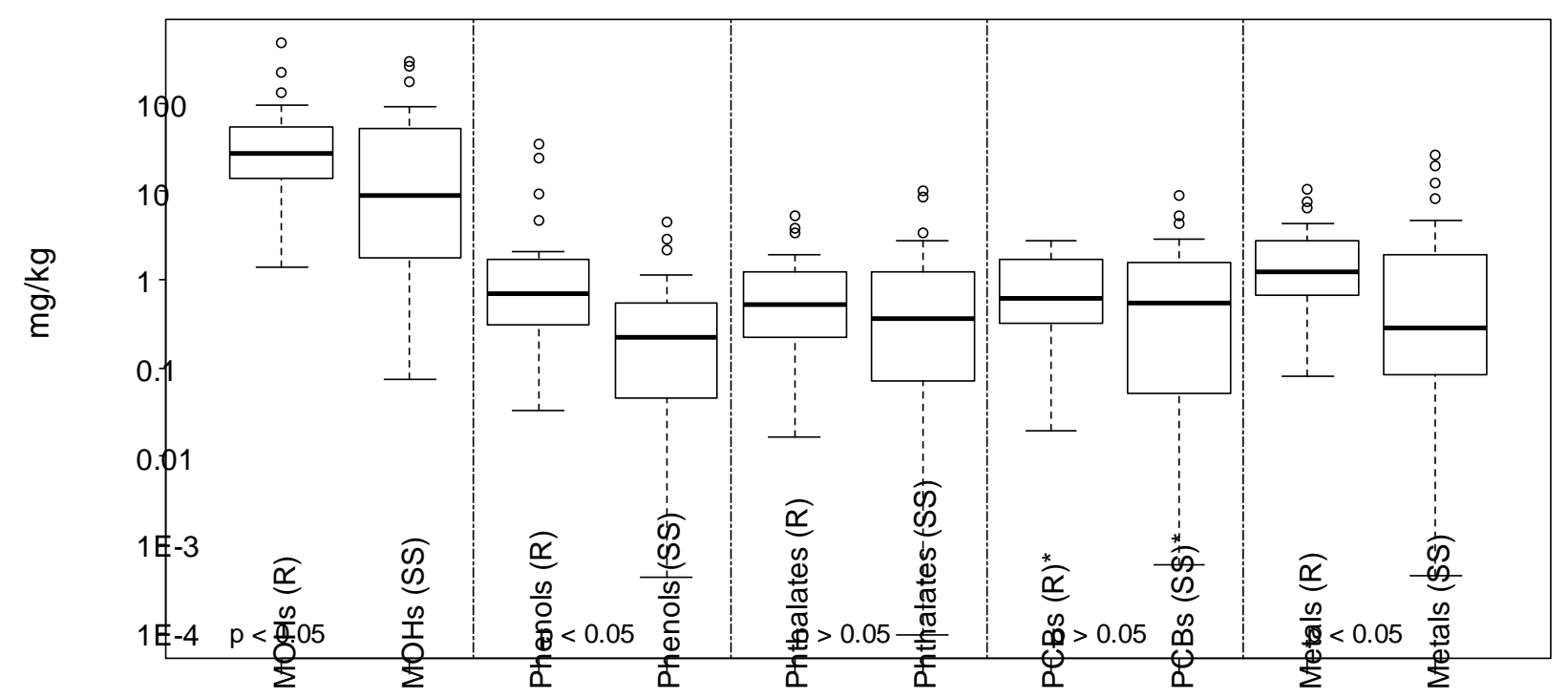

Figure 4. Box plots of chemicals analysed in the present study (logarithmic scale). R: residual waste paper; SS: source-segregated waste paper $(\mathrm{mg} / \mathrm{kg} \mathrm{dm})$. The $p$ - values indicate significant $(p<0.05)$ or non-significant $(p>0.05)$ difference between residual and source-segregated waste paper. ${ }^{*}$ Values for PCBs are in $\mu \mathrm{g} / \mathrm{kg} \mathrm{dm}$.

those in the residual flow. When the log-transformed concentrations for both flows were compared using the Student's $t$-test, only phthalates and PCBs showed no significant difference ( $p$-value $>$ 0.05), while MOHs, phenols, and metals were all significantly different from one flow to the other. This could indicate that potential cross-contamination during collection, and potential differences in 
the use or disposal patterns for the individual paper and board items in the two waste flows, have a significant influence on the total content of MOHs, phenols, and metals in the paper matrices. For the three chemical groups mentioned, the median concentrations found in the residual flow were higher than those found in the source-segregated flow.

\subsection{Implications of the results}

The presence of chemicals in waste paper has the potential to result in the persistence or spreading of chemicals through the paper recycling processes and the re-introduction of unwanted chemicals into newly manufactured products. Although paper is treated in order to remove certain contaminants (including chemicals) during the recycling process (e.g., pulping, de-inking, cleaning, bleaching), the efficiency of these removal processes with respect to chemical contamination remains questionable (BMELV, 2012; Jamnicki et al., 2012). For example, we cannot expect mineral oils, as hydrophobic chemicals, to be sufficiently removed in a conventional paper recycling process. Previously reported flotation de-inking experiments have shown a removal rate of less than $50 \%$ for semi-volatile organic compounds (including mineral oil components) (Schabel, 2011). The fact that up to $2,200 \mathrm{mg} / \mathrm{kg}$ of mineral oils have been observed in pulp from recycling and paper products containing recycled fibres may be a result of this (Biedermann and Grob, 2010; BMELV, 2012). Additionally, number or steps employed in paper recycling and specific conditions for each of these steps (e.g., $\mathrm{pH}$, temperature, residence time, type of chemicals used, etc.) will influence the final efficiency of contaminant removal. For example, removal efficiency of BPA decreased from $95 \%$ to $10 \%$ for paper recycling sites with and without deinking stage, respectively (JRC-IHCP, 2008). Where the paper industry has recognized the issues concerning chemicals, some measures against the spreading of contaminants into food-contact materials have already been taken. The existing industry guidelines on the compliance of paper and board articles for food-contact applications specify, among other things, limit values for polycyclic 
aromatic hydrocarbons, selected phenols, phthalates and toxic metals in final food-contact paper and board articles (CEPI, 2012). Nevertheless, effects of selected chemicals with endocrinedisrupting potential (e.g., NP, OP, BPA, BBP, DBP, DEHP, etc.) is an area of active scientific research, and the currently used limit-values might be misleading. As an example, recent significant reduction (from $50 \mu \mathrm{g} / \mathrm{kg}_{\mathrm{bw}} / \mathrm{d}$ to $4 \mu \mathrm{g} / \mathrm{kg}_{\mathrm{bw}} / \mathrm{d}$ ) in safe levels of BPA (EFSA, 2015), has not been reflected in industry's guidelines. Additionally, the results of our study clearly indicate that the list of chemicals potentially present in recycled paper might be longer than the selected chemicals already regulated. Take the example of PCBs: although they have been banned in most of the world for decades, the PCB measurements in this study indicate a relatively slow process of contaminant removal from the paper cycle, as a result of the long lifespan of certain paper items and the potential persistence of chemicals in the recycling process. The results show that board fractions had higher PCBs levels than paper, potentially as a result of material recycling (since board recycling rates are generally higher than paper recycling rates) (CEPI, 2014). Older studies have shown the presence of PCBs only in recycled paper (Storr-Hansen and Rastogi, 1988). The concentrations found in our study (between 13 and $320 \mu \mathrm{g} / \mathrm{kg}$ ), although comparable to the results of other recent studies (Binderup et al., 2002), are substantially lower than the concentrations found in paper three decades ago (between 100 and 12,400 $\mu \mathrm{g} / \mathrm{kg}$ ) (Voogt et al., 1984). This may indicate the gradual removal of PCBs from the paper cycle, as a result of the ban.

To ensure a high quality of paper and board for recycling, the chemicals of concern can be substituted by alternatives of reduced hazard. For example, vegetable oils can be used in place of mineral oils in printing process (Roy et al., 2007), while variety of phenol-based and phenol-free alternatives to BPA can be used in thermal paper (US EPA, 2014). Alternatively, fractions with high levels of problematic chemicals could potentially be removed from the source-segregated flows sent to recycling. Based on data such as those reported in this study, updated sorting guides 
for waste paper and board could be developed. Excluding fractions containing high concentrations of chemicals from source segregation, and instead routing these materials, e.g., to incineration, could contribute to the phasing out of specific chemicals. Based on our results, the fractions most relevant for exclusion from source-segregation are i) thermal paper receipts (due to their phenol content), ii) kraft paper and board composites (due to their phthalate content), and iii) books (due to their high PCB content). When considering potential control measures for mitigation of chemical contamination in paper cycle, both concentration of hazardous chemicals in a waste paper fraction and mass of a fraction in the total paper should be considered.

\section{Conclusions}

Waste paper and board contains measurable levels of MOHs, phenols, phthalates, PCBs, and selected toxic metals. Although the chemicals present in paper and board are not uniformly distributed among paper and board fractions, a detailed fractionation of paper and board in household waste offered in-depth data for chemical contents in individual fractions collected as part of the residual and source-segregated waste flows, respectively. The results indicate that paper fractions differ in terms of the chemicals concentrations in the two waste paper flows considered. The significant differences found in the concentrations of MOHs, phenols, and metals between residual and source-segregated flows should receive specific attention when planning waste collection and management activities. The fate of chemicals in paper recycling processes is not sufficiently well documented to allow a specific evaluation of the potential implications of the presence of these chemicals on recyclability. However, the results provided by this study clearly indicate that certain paper and board fractions (i.e. thermal paper receipts, kraft paper, composites, and books) contain relatively high concentrations of problematic chemicals. Both the paper industry and the waste management authorities should be aware of the presence of chemicals in paper 
materials destined for recycling, in order to help maintain the high paper recycling rates without compromising the quality of the products manufactured.

\section{Acknowledgements}

The authors would like to acknowledge the support from Christina Maj Hagberg and Morten Andreasen in the analytical part of the work. The Danish Research Council is acknowledged for financial support through the 3R Research School and the IRMAR project (grant no. 11-116775).

\section{Supplementary material}

Supplementary data containing the detailed results of chemical composition of residual and sourcesegregated waste paper fractions (Tables S1-S10) can be found, in the online version, at http://dx.doi.org/10.1016/j.wasman.2016.03.008.

\section{References}

Albro, P., Parker, C., 1979. Comparison of the compositions of Aroclor 1242 and Aroclor 1016. J. Chromatogr. A 69, 161-166.

Algreen, M., Rein, A., Legind, C.N., Amundsen, C.E., Karlson, U.G., Trapp, S., 2012. Test of Tree Core Sampling for Screening of Toxic Elements in Soils from a Norwegian Site. Int. J. Phytoremediation 14, 305-319. doi:10.1080/15226514.2011.620648

Algreen, M., Trapp, S., Rein, A., 2013. Phytoscreening and phytoextraction of heavy metals at Danish polluted sites using willow and poplar trees. Environ. Sci. Pollut. Res. Int. doi:10.1007/s11356-013-2085-z

Alonso, M.., Puig, D., Silgoner, I., Grasserbauer, M., Barceló, D., 1998. Determination of priority phenolic compounds in soil samples by various extraction methods followed by liquid chromatography-atmospheric pressure chemical ionisation mass spectrometry. J. Chromatogr. A 823, 231-239. doi:10.1016/S0021-9673(98)00110-1

Biedermann, M., Grob, K., 2010. Is recycled newspaper suitable for food contact materials? Technical grade mineral oils from printing inks. Eur. Food Res. Technol. 230, 785-796. doi:10.1007/s00217-010-1223-9

Biedermann, M., Grob, K., 2012. On-line coupled high performance liquid chromatography-gas chromatography for the analysis of contamination by mineral oil. Part 2: migration from paperboard into dry foods: interpretation of chromatograms. J. Chromatogr. A 1255, 76-99. doi:10.1016/j.chroma.2012.05.096

Biedermann, S., Tschudin, P., Grob, K., 2010. Transfer of bisphenol A from thermal printer paper 
to the skin. Anal. Bioanal. Chem. 398, 571-6.

Binderup, M.L., Pedersen, G.A., Vinggaard, A.M., Rasmussen, E.S., Rosenquist, H., Cederberg, T., 2002. Toxicity testing and chemical analyses of recycled fibre-based paper for food contact. Food Addit. Contam. 19 Suppl, 13-28.

BIR, 2012. BIR global facts \& figures. Recovered paper market in 2012, Bureau of International Recycling (BIR). Brussels, Belgium.

Björklund, A., Finnveden, G., 2005. Recycling revisited—life cycle comparisons of global warming impact and total energy use of waste management strategies. Resour. Conserv. Recycl. 44, 309-317. doi:10.1016/j.resconrec.2004.12.002

BMELV, 2012. Ausmaß der Migration unerwünschter Stoffe aus Verpackungsmaterialien aus Altpapier in Lebensmitteln, BMELV (German Federal Ministry of Food, Agriculture and Consumer Protection) [WWW Document]. URL http://download.ble.de/09HS012.pdf (accessed 11.19.15).

Breivik, K., Sweetman, A., Pacyna, J.M., Jones, K.C., 2007. Towards a global historical emission inventory for selected PCB congeners--a mass balance approach 3. An update. Sci. Total Environ. 377, 296-307. doi:10.1016/j.scitotenv.2007.02.026

CEPI, 2012. Industry Guideline for the Compliance of Paper \& Board Materials and Articles for Food Contact, Confederation of European Paper Industries (CEPI). Brussels, Belgium.

CEPI, 2014. Key Statistics. European Pulp and Paper Industry 2014, Confederation of European Paper Industries (CEPI). Brussels, Belgium.

Choi, B.-C., Shin, H.-S., Lee, S.-Y., Hur, T., 2004. Life Cycle Assessment of a Personal Computer and its Effective Recycling Rate. Int. J. Life Cycle Assess. 11, 122-128. doi:10.1065/lca2004.12.196

Cote, M., Poganietz, W.-R., Schebek, L., 2014. Anthropogenic Carbon Stock Dynamics of Pulp and Paper Products in Germany. J. Ind. Ecol. 366-379. doi:10.1111/jiec.12210

Dömötörová, M., Sejáková, Z.S., Kočan, A., Čonka, K., Chovancová, J., Fabišiková, A., 2012. PCDDs, PCDFs, dioxin-like PCBs and indicator PCBs in soil from five selected areas in Slovakia. Chemosphere 89, 480-5. doi:10.1016/j.chemosphere.2012.05.106

Droz, C., Grob, K., 1997. Determination of food contamination by mineral oil material from printed cardboard using on-line coupled LC-GC-FID. Zeitschrift für Leb. und -forsch. A 239-241.

EC, 1984. Council directive of 15 October 1984 on the approximation of the laws of the Member States relating to ceramic articles intended to come into contact with foodstuffs. Off. J. Eur. Union L 277, 1-8.

EC, 2003. Directive 2003/53/EC of the European parliament and of council of 18 June 2003 amending for the 26th time Council Directive 76/769/EEC relating to restrictions on the marketing and use of certain dangerous substances and preparations (nonylphenol, nonylph. Off. J. Eur. Union L 178, 24-27.

EC, 2004. Regulation No 1935/2004 of the European Parliament and of the Council of 27 October 2004 on materials and articles intended to come into contact with food and repealing Directives 80/590/EEC and 89/109/EEC. Off J Eur Union L 338, 4-17.

EC, 2005. Directive 2005/84/EC of the European Parliament and of the council of 14 December 
2005 amending for the 22nd time Council Directive 76/769/EEC on the approximation of the laws, regulations and administrative provisions of the Member States relating to res. Off. J. Eur. Union L 344, 40-43.

EC, 2006. Commission regulation (EC) No 2023/2006 of 22 December 2006 on good manufacturing practice for materials and articles intended to come into contact with food. Off. J. Eur. Union L 384, 75-78.

EC, 2008. Commission regulation (EC) No 282/2008 of 27 March 2008 on recycled plastic materials and articles intended to come into contact with foods. Off. J. Eur. Union L 86, 9-18.

EC, 2011. Commission regulation (EU) No 1259/2011 of 2 December 2011 amending Regulation (EC) No 1881/2006 as regards maximum levels for dioxins, dioxin-like PCBs and non dioxinlike PCBs in foodstuffs. Off. J. Eur. Union L 320, 18-23.

EC, 2015. Closing the loop - An EU action plan for the Circular Economy, Communication from the Commission to the European Parliament, the Council, the European Economic and Social Committee and the Committee of the Regions, COM(2015) 614, Brussels, Belgium.

Edjabou, M.E., Jensen, M.B., Götze, R., Pivnenko, K., Petersen, C., Scheutz, C., Astrup, T.F., 2015. Municipal solid waste composition: Sampling methodology, statistical analyses, and case study evaluation. Waste Manag. 36, 12-23. doi:10.1016/j.wasman.2014.11.009

EFSA, 2012. Scientific Opinion on Mineral Oil Hydrocarbons in Food. EFSA J. 10(6), 2704-2889.

EFSA, 2015. Scientific Opinion on the risks to public health related to the presence of bisphenol A (BPA) in foodstuffs. EFSA J. 13, 1-23. doi:10.2903/j.efsa.2015.3978

Eganhouse, R.P., Pontolillo, J., Gaines, R.B., Frysinger, G.S., Gabriel, F.L.P., Kohler, H.-P.E., Giger, W., Barber, L.B., 2009. Isomer-specific determination of 4-nonylphenols using comprehensive two-dimensional gas chromatography/time-of-flight mass spectrometry. Environ. Sci. Technol. 43, 9306-13. doi:10.1021/es902622r

Erickson, M.D., Kaley, R.G., 2011. Applications of polychlorinated biphenyls. Environ. Sci. Pollut. Res. Int. 18, 135-51. doi:10.1007/s11356-010-0392-1

EU, 2011a. Commission regulation (EU) No 10/2011 of 14 January 2011 on plastic materials and articles intended to come into contact with food. Off. J. Eur. Union L 12, 1-89.

EU, 2011b. Commission regulation (EU) No 143/2011 of 17 February 2011 amending Annex XIV to Regulation (EC) No 1907/2006 of the European Parliament and of the Council on the Registration, Evaluation, Authorisation and Restriction of Chemicals ("REACH”). Off. J. Eur. Union L 44, 2-6.

Frame, G.M., Cochran, J.W., Bøwadt, S.S., 1996. Complete PCB congener distributions for 17 aroclor mixtures determined by 3 HRGC systems optimized for comprehensive, quantitative, congener-specific analysis. J. High Resolut. Chromatogr. 19, 657-668. doi:10.1002/jhrc.1240191202

Fromme, H., 2011. Phthalates: Human Exposure, in: Encyclopedia of Environmental Health. Elsevier, pp. 498-510. doi:10.1016/B978-0-444-52272-6.00607-3

Gärtner, S., Balski, M., Koch, M., Nehls, I., 2009. Analysis and migration of phthalates in infant food packed in recycled paperboard. J. Agric. Food Chem. 57, 10675-81.

doi:10.1021/jf902683m 
Gehring, M., Tennhardt, L., Vogel, D., 2004. Bisphenol A contamination of wastepaper, cellulose and recycled paper products, in: Brebbia, C.A., Kungolos, S., Popov, V., Itoh, H. (Eds.), Waste Management and the Environment II. WIT Press, pp. 293-301.

Hermanson, M.H., Johnson, G.W., 2007. Polychlorinated biphenyls in tree bark near a former manufacturing plant in Anniston, Alabama. Chemosphere 68, 191-198.

Hutzinger, O., Safe, S., Zitko, V., 1974. The chemistry of PCB’s. CRC Press, Cleveland, OH, USA.

Jamnicki, S., Lozo, B., Rutar, V., Barušić, L., 2012. A study on the food contact suitablity of recycled paper and board. Papiripar 14-20.

JRC-IHCP, 2008. European Union Risk Assessment Report: 4, 4'-isopropylidenediphenol (Bisphenol-A). Eur. Union 2008, 201-245. doi:10.2788/40195

Kabacoff, R.I., 2011. R in action. Data analysis and graphics with R. Manning Publications, Shelter Island, NY, USA.

Kassa, H., Bisesi, M.S., 2001. Levels of polychlorinated biphenyls (PCBs) in fish: the influence on local decision making about fish consumption. J. Environ. Health 63, 29-35.

Latorre, A., Rigol, A., Lacorte, S., Barceló, D., 2005. Organic compounds in paper mill wastewaters, in: Barceló, D. (Ed.), The Handbook of Environmental Chemistry. SpringerVerlag, Berlin/Heidelberg, pp. 25-51. doi:10.1007/b97783

Laurijssen, J., Marsidi, M., Westenbroek, A., Worrell, E., Faaij, A., 2010. Paper and biomass for energy? Resour. Conserv. Recycl. 54, 1208-1218. doi:10.1016/j.resconrec.2010.03.016

Liao, C., Kannan, K., 2011a. Widespread occurrence of bisphenol A in paper and paper products: implications for human exposure. Environ. Sci. Technol. 45, 9372-9. doi:10.1021/es202507f

Liao, C., Kannan, K., 2011b. High levels of bisphenol A in paper currencies from several countries, and implications for dermal exposure. Environ. Sci. Technol. 45, 6761-8. doi:10.1021/es200977t

Lorenzini, R., Biedermann, M., Grob, K., Garbini, D., Barbanera, M., Braschi, I., 2013. Migration kinetics of mineral oil hydrocarbons from recycled paperboard to dry food: monitoring of two real cases. Food Addit. Contam. Part A. Chem. Anal. Control. Expo. Risk Assess. 30, 760-70. doi:10.1080/19440049.2013.766765

Lorenzini, R., Fiselier, K., Biedermann, M., Barbanera, M., Braschi, I., Grob, K., 2010. Saturated and aromatic mineral oil hydrocarbons from paperboard food packaging: estimation of longterm migration from contents in the paperboard and data on boxes from the market. Food Addit. Contam. Part A. Chem. Anal. Control. Expo. Risk Assess. 27, 1765-74. doi:10.1080/19440049.2010.517568

MACTac, 2013. Product data : MAClux - REMOVABLE FSC certified [WWW Document]. URL http://www.mactac.eu/datas/products_docs/m/a/maclux-removable-secury-9-fscnew/52e7ba0e50c09-maclux-removable-secury-9-fsc-new.pdf (accessed 11.20.15).

Martín-Fernández, J., Barcelo-Vidal, C., Pawlowsky-Glahn, V., 2003. Dealing with zeros and missing values in compositional data sets using nonparametric imputation. Math. Geol. 35, 253-278.

McLaughlin, M.J., Smolders, E., Degryse, F., Rietra, R., 2011. Uptake of Metals from Soil into Vegetables, in: McLaughlin, M.J., Smolders, E., Degryse, F., Rietra, R. (Eds.), Dealing with 
Contaminated Sites: From Theory towards Practical Application. Springer Netherlands, Dordrecht, pp. 325-367. doi:10.1007/978-90-481-9757-6_8

Miljøstyrelsen, 2003. Survey of chemical substances in paper handkerchiefs and toilet paper. Survey of chemical substances in consumer products No. 34, Miljøstyrelsen (Danish EPA). Copenhagen, Denmark..

Miljøstyrelsen, 2011. Kemikaliesubstitution i grafisk branche, Miljøproject Nr. 1354, Miljøstyrelsen (Danish EPA). Copenhagen, Denmark.

Miranda, R., Bobu, E., Grossmann, H., Stawicki, B., Blanco, A., 2010. Factors influencing a higher use of recovered paper in the european paper industry. Cellul. Chem. Technol. 44, 419-430.

Miranda, R., Monte, M.C., Blanco, A., 2013. Analysis of the quality of the recovered paper from commingled collection systems. Resour. Conserv. Recycl. 72, 60-66. doi:10.1016/j.resconrec.2012.12.007

Morales, S., Canosa, P., Rodríguez, I., Rubí, E., Cela, R., 2005. Microwave assisted extraction followed by gas chromatography with tandem mass spectrometry for the determination of triclosan and two related chlorophenols in sludge and sediments. J. Chromatogr. A 1082, 128135. doi:10.1016/j.chroma.2005.05.059

Muncke, J., 2009. Exposure to endocrine disrupting compounds via the food chain: Is packaging a relevant source? Sci. Total Environ. 407, 4549-59. doi:10.1016/j.scitotenv.2009.05.006

National Research Council, 2008. Phthalates and Cumulative Risk Assessment The Task Ahead. The National Academies Press, Washington, DC, USA. doi:10.17226/12528

Nordtest, 1995. Municipal solid waste: Sampling and characterisation (No. NT ENVIR 001), Nordtest Method. Espoo, Finland.

Östberg, T., Noaksson, E., 2010. Bisfenol A in svenska kvitton. Analysresultat. Institutet för tillämpad Grön kemi, Jegrelius (Institute for Applied Green Chemistry). Östersund, Sweden.

Parry, S.J., Aston, D.S.J., 2004. Migration of inorganic contaminants into dry food from packaging made from recycled paper and board. Food Addit. Contam. 21, 506-11. doi:10.1080/02652030410001677808

Pérez-Palacios, D., Fernández-Recio, M.Á., Moreta, C., Tena, M.T., 2012. Determination of bisphenol-type endocrine disrupting compounds in food-contact recycled-paper materials by focused ultrasonic solid-liquid extraction and ultra performance liquid chromatography-high resolution mass spectrometry. Talanta 99, 167-74. doi:10.1016/j.talanta.2012.05.035

Petersen, L., Minkkinen, P., Esbensen, K.H., 2005. Representative sampling for reliable data analysis: Theory of Sampling. Chemom. Intell. Lab. Syst. 77, 261-277.

doi:10.1016/j.chemolab.2004.09.013

Pivnenko, K., Eriksson, E., Astrup, T.F., 2015a. Waste paper for recycling: Overview and identification of potentially critical substances. Waste Manag. doi:10.1016/j.wasman.2015.02.028

Pivnenko, K., Pedersen, G.A., Eriksson, E., Astrup, T.F., 2015b. Bisphenol A and its structural analogues in household waste paper. Waste Manag. 44, 39-47. doi:10.1016/j.wasman.2015.07.017

Poças, M.F., Oliveira, J.C., Pereira, J.R., Hogg, T., 2010. Consumer exposure to phthalates from 
paper packaging: an integrated approach. Food Addit. Contam. Part A. Chem. Anal. Control. Expo. Risk Assess. 27, 1451-9.

Reimann, C., Filzmoser, P., Garrett, R., Dutter, R., 2008. Statistical Data Analysis Explained: Applied Environmental Statistics with R, John Wiley \& Sons, Inc. Hoboken, NJ, USA.

Riber, C., Petersen, C., Christensen, T.H., 2009. Chemical composition of material fractions in Danish household waste. Waste Manag. 29, 1251-7.

Rotter, V.S., Kost, T., Winkler, J., Bilitewski, B., 2004. Material flow analysis of RDF-production processes. Waste Manag. 24, 1005-21.

Roy, A.S., Bhattacharjee, M., Mondal, R., Ghosh, S., 2007. Development of mineral oil free offset printing ink using vegetable oil esters. J. Oleo Sci. 56, 623-8. doi:10.5650/jos.56.623

Salhofer, S., Obersteiner, G., Schneider, F., Lebersorger, S., 2008. Potentials for the prevention of municipal solid waste. Waste Manag. 28, 245-59. doi:10.1016/j.wasman.2007.02.026

Sanchez, V.M., Møller, J., 2011. LCA on the prevention of unsolicited mail in the Vestforbrænding municipalities, Department of Environmental Engineering, Technical University of Denmark, Kgs. Lyngby, Denmark.

Schabel, S., 2011. Mineral oils and other volatile contaminants in printed paper and board and measures for removal in recovered paper processing, in: Wang, L., Kuang, S., Hou, Q., Cao, C., Si, C., Zhang, H. (Eds.), Proceedings of the Sixteenth International Symposium on Wood, Fiber and Pulping Chemistry. China Light Industry Press, Tianjin, China.

Schossler, P., Schripp, T., Salthammer, T., Bahadir, M., 2011. Beyond phthalates: gas phase concentrations and modeled gas/particle distribution of modern plasticizers. Sci. Total Environ. 409, 4031-8. doi:10.1016/j.scitotenv.2011.06.012

Storr-Hansen, E., Rastogi, S.C., 1988. Polychlorinated biphenyls and heavy metal levels in recycled paper for household use. Bull. Environ. Contam. Toxicol. 40, 451-456.

Summerfield, W., Cooper, I., 2001. Investigation of migration from paper and board into food-development of methods for rapid testing. Food Addit. Contam. 18, 77-88. doi:10.1080/02652030010004674

Sundhedsstyrelsen, 2013. Health risks of PCB in the indoor climate in Denmark - background for setting recommended action levels, Sundhedsstyrelsen (Danish Health and Medicines Authority). Copenhagen, Denmark.

The World Bank, 2012. What a waste: A global review of solid waste management. Washington, DC, USA.

Thormark, C., 2001. Conservation of energy and natural resources by recycling building waste. Resour. Conserv. Recycl. 33, 113-130. doi:10.1016/S0921-3449(01)00078-7

Triantafyllou, V., Akrida-Demertzi, K., Demertzis, P., 2007. A study on the migration of organic pollutants from recycled paperboard packaging materials to solid food matrices. Food Chem. 101, 1759-1768. doi:10.1016/j.foodchem.2006.02.023

US EPA, 1976. PCBs in the United States Industrial Use and Environmental Distribution, Final report. U.S. Environmental Protection Agency (EPA). Washington, DC, USA.

US EPA, 1977. PCBs involvement in the pulp and paper industry. U.S. Environmental Protection 
Agency (EPA). Washington, DC, USA.

US EPA, 2010. Screening-level hazard characterization, Phthalate Esters Category. U.S. Environmental Protection Agency (EPA). Washington, DC, USA.

US EPA, 2014. Bisphenol A alternatives in thermal paper. U.S. Environmental Protection Agency (EPA). Washington, DC, USA.

Villanueva, A., Wenzel, H., 2007. Paper waste - recycling, incineration or landfilling? A review of existing life cycle assessments. Waste Manag. 27, S29-46. doi:10.1016/j.wasman.2007.02.019

Voogt, P., Klamer, J.C., Brinkman, U.A.T., 1984. Identification and quantification of polychlorinated biphenyls in paper and paper board using fused silica capillary gas chromatography. Bull. Environ. Contam. Toxicol. 32, 45-52. doi:10.1007/BF01607463 